\title{
The Effect of Regulation on the Relationship between Earnings and Stock Returns
}

\author{
Doina C. Chichernea ${ }^{1} \&$ Diana R. Franz ${ }^{1}$ \\ ${ }^{1}$ College of Business and Innovation, University of Toledo, USA \\ Correspondence: Doina Chichernea, College of Business and Innovation, Department of Finance, MS. 103, $2801 \mathrm{~W}$. \\ Bancroft St., Toledo, OH 43606-3390, USA. Tel: 1-419-530-2437. E-mail: doina.chichernea@utoledo.edu \\ Received: July 6, 2016 \\ Accepted: July 31, 2016 \\ Online Published: August 7, 2016 \\ doi:10.5430/afr.v5n3p127 \\ URL: http://dx.doi.org/10.5430/afr.v5n3p127
}

\begin{abstract}
We document that disclosure and analyst regulatory changes made between 2000 and 2003 significantly diminished the magnitude of the relationship between earnings and market returns. While we observe no significant change in the relationship between returns and earnings components (i.e. cash-flows and accruals), earnings components' persistence has significantly declined post-regulation. We interpret this as evidence that a decrease in earnings quality impacted the strength of the earnings-returns relation. We find no significant change when using an international sample control group, which strengthens the claim that the weakened earnings-returns relation found for the U.S. firms is due to regulatory changes.
\end{abstract}

Keywords: Earnings, Accruals, Regulation, SOX, Earnings persistence

\section{Introduction, Background and Hypotheses}

\subsection{Introduction}

The importance of accounting measures, particularly earnings, to stock returns addresses the key issue of the relevance of financial reporting and has been a topic of ongoing interest in the literature. By facilitating the prediction of firms' future cash flows and helping investors assess securities' risks and returns, earnings numbers are seminal for capital markets research. Early accounting literature has devoted much attention to the relevance of earnings information for stock returns, starting with the influential work of Ball and Brown, 1968.

More recent literature has branched away from this root question into several more focused areas of interest such as earnings quality/earnings management, the use of discretionary/non-discretionary accruals, etc. (see section 2 for a review of the literature development). Considering the vast amount of early work dedicated to answering the basic question about the general relation between earnings and returns, it is understandable that most studies consider it a resolved subject. Nichols and Wahlen, 2004 is the most recent study specifically replicating Ball and Brown, 1968 in the U.S. markets and it uses data from 1988 through 2002.

\subsection{Importance of the Relationship between Earnings and Returns and Why Reexamine It}

Our study reexamines the core relation between earnings and returns using data through 2012. We are interested in whether the relationship between earnings and returns has changed after the extensive regulatory changes in the reporting environment made between the years 2000 and 2003. These regulatory changes include Regulation Fair Disclosure (Reg FD), the Sarbanes-Oxley Act (SOX), and several analyst regulations. As Lee, Strong, \& Zhu, 2014 indicate, these disclosure and analyst regulations were intended "to improve the corporate information environment and restore investor confidence"; however, literature provides mixed results on the net effect of these regulatory changes.

While the individual impact of Reg FD and SOX on capital markets and on disclosures has generated extensive research, the root relation between total earnings and returns has surprisingly not been reexamined. This study fills that gap. Specifically, we investigate the relationship between earnings and returns using the analysis framework of Nichols and Wahlen (2004). We incorporate Lee et al.'s (2014) definition of the transition period and the use of a comparison sample of European firms that are unaffected by the regulatory changes in the U.S. markets.

There are multiple reasons to believe that the aforementioned regulatory changes would affect the relevance of earnings for market participants. The observed relation between earnings and returns is likely to reflect a 
combination of different dynamic factors, such as the information content in earnings, earnings persistence, market efficiency and the asset pricing process (Nichols and Wahlen, 2004). Because the intent of these disclosure and analyst regulations was to restore investors' confidence in the financial reporting process and environment, the observed relationships should have changed if the regulations were effective. However, most researchers have attempted to study the effect of individual regulatory changes on each of these factors and have moved away from documenting the net result. We fill this gap by answering a very simple question: has the core relation between earnings and returns significantly changed after these regulatory changes in the U.S. markets?

\subsection{Prior Research}

\subsubsection{Earnings and Returns}

The link between accounting earnings and market returns predicates on the notion that both contain information about expected future profitability of a given firm. Since Ball and Brown, 1968, researchers have repeatedly demonstrated that positive firm-level earnings changes result in increased stock prices and positive returns. Under the efficient market hypothesis, this association is commonly viewed as a price reaction to cash flow news, where changes in earnings reflect changes in expected cash flows. To the extent that the firm's current value is the present value of future cash flows (i.e. future dividends to the shareholder), this documented positive association supports the idea that higher earnings increase expected cash-flows, and in turn generate positive firm-level stock returns. (Note 1)

Early literature on the information content of earnings dates back to Beaver, 1968 and Ball and Brown, 1968, who provide evidence that investors change their equity valuation in response to earnings announcements. This original evidence has been revisited in the literature from time to time. For example, responding to concerns about degradation in the usefulness and timeliness of accounting earnings, Landsman and Maydew, 2002 provide results which suggest that over time there has been an increase in the informativeness of quarterly earnings announcements. Nichols and Wahlen, 2004 replicate the original Ball and Brown results using data up to 2002. In general, most of the more recent literature on the information content of earnings revolves around some variation of earnings response coefficients methods (ERC), which are intended to measure investors' responsiveness to earnings (see, for example, Liu \& Thomas, 2000). (Note 2)

The second topic of earnings persistence is also abundant in the accounting literature and is sometimes used as a proxy for earnings quality (see Dechow, Ge, \& Schrand, 2010 and Benson, Clarkson, Smith and Tutticci (2015) for a review of earnings quality/earnings persistence literature). Persistent earnings assume a high likelihood that a given firm's earnings level will recur in a future period, and under the assumption of market efficiency, they are essential to the first link identified by Nichols and Wahlen. To the extent that a given firm posts comparatively less persistent (i.e. more transitory) earnings, these earnings should say less about future periods' earnings, thus resulting in a weakened relation with returns. The stronger the link between current and future earnings (i.e. the more persistent earnings are), the more informative earnings are supposed to be, and the more likely it is that returns would react to this information. Early research by Kormendi and Lipe, 1987, Collins and Kothari, 1989, and Easton and Zmijewski, 1989 provide evidence that more persistent earnings are associated with a stronger stock price response. Even without the assumption of market efficiency, earnings persistence is important for market returns. The most predominant example being the Sloan, 1996 hypothesis for the accrual anomaly which postulates that investors cannot differentiate between the different persistence of earnings and accruals. This seminal paper has started an extremely prolific strand of research into the relation between components of earnings and returns, and in particular components of accruals and returns. Richardson, Tuna, \& Wysocki, 2010 provides an extensive review of accounting anomalies and fundamental analysis.

Overall, the general conclusion that can be derived from the literature is that earnings are related to market values. Furthermore, accruals help improve the ability of earnings to reflect value. Thus, earnings appear to be a more useful measure than cash flows in studies related to market returns.

\subsubsection{Earnings and Regulatory Changes}

From October 2000 through November of 2002, several significant regulatory changes were enacted that affected the U.S. capital markets. These changes were intended to improve the information available and to restore investor confidence. The first regulatory change was Regulation Fair Disclosure (Reg FD) which was issued by the Securities and Exchange Commission with an effective date of October 23, 2000 (SEC (2000)). Reg FD was issued in response to concern at the SEC about firms making selective disclosures of material information. Reg FD addressed this 
concern by requiring that publicly traded firms which make selective disclosures of material nonpublic information to groups or individuals must also publicly disclose that information (SEC (2000)).

Empirical evidence has documented that information asymmetry declined after Reg FD was issued (Eleswarapu, Thompson, \& Venkataraman, 2004; Heflin, Subramanyam, \& Zhang, 2003; Eng, Ha, \& Nabar, 2013). The empirical evidence about management's earnings guidance post Reg FD is mixed. Herrmann, Kang, \& Kim, 2010 document that the firms in their sample issued fewer forecast and that the quality of the forecasts issued had declined. Alternatively, Stunda, 2012 concluded that number of and quality of forecasts increased after Reg FD was issued. Griffin, Lont and Segal (2011) concluded that Reg FD imposed additional costs on investors. Furthermore, as documented by Chang, Kim, Kim and Thornton (2012) in the Korea markets, regulation intended to promote fairness can result in unintended economic distortions. Koch, Lefanowicz, \& Robinson, 2013 provide a survey of the academic literature about Reg FD (2013).

The second regulatory change was the Sarbanes-Oxley Act (SOX) which was passed into law following numerous well-publicized accounting frauds such as Enron and WorldCom that occurred between 2000 and 2002. Given that one of its goals is to provide incentives for firms to report financial results that reflect the underlying economic performance (thus to restore investors' confidence in external financial reporting), this regulation seems particularly relevant to the earnings-return relation. SOX made extensive changes to corporate reporting for U.S. firms and the auditors of those firms.

The passage of SOX receives mixed responses in the literature with respect on its effect on earnings reporting and valuation. A number of studies report increases in earnings quality and sharp declines in discretionary accruals in the post-SOX periods (e.g., Lobo \& Zhou, 2006, 2010; Chang, Fernando, \& Liao, 2009; Altamuro \& Beatty, 2010; Cohen, Dey, \& Lys, 2008; Jain \& Rezaee, 2006; Li, Pincus, Olhoft, \& Olhoft, 2008). Black, Black, Christensen, \& Heninger, 2012 study the effect of SOX on pro forma earnings disclosures and show that the quality of pro-forma reporting has improved and investors' perceptions of pro forma earnings metrics has changed after the passage of SOX. Iliev, 2010 finds that SOX imposes huge costs on firms but also reports material declines in total accruals and in discretionary accruals following SOX.

Kalelkar and Nwaeze, 2011 investigate the extent to which the passage of SOX is associated with more or less investor confidence in earnings and earnings components, with a particular focus on discretionary accruals (which is the component of earnings alleged to be most vulnerable to manipulation). Overall, their results show increases in the valuation weights of earnings and earnings components subsequent to the passage of SOX, which are primarily driven by the pricing actions of unsophisticated investors. The authors interpret these results as evidence that SOX has been successful in leveling the information field across sophisticated and unsophisticated investors.

Other researchers have investigated the impact of SOX on earnings management. Li et al. (2008) found a significant and positive relationship between a firm's abnormal returns around a SOX related event and the extent of that firm's earnings management. They interpret this evidence as indicating that investors expected SOX to constrain earnings management and have a greater impact on the quality of financial reporting when firm's had engaged in more extensive amounts of earnings management. Zhou, 2008 documented that post-SOX firms reported more conservatively based on lower discretionary accruals and engaged in less overall earnings management based on lower absolute values of discretionary accruals. In contrast, Franz et al. (2014) find that post-SOX, firms with a stronger incentive to manage earnings, had more total earnings management. This was driven by these firms using more real earnings management but less accounting earnings management.

The final regulatory changes that we include are four changes that affect analysts (Lee et al. (2014)). The National Association of Security Dealers (NASD) issued Rule 2711 Research Analysts and Research Reports. This rule sought to strengthen the role of the analyst and to eliminate communication between analysts and investment banking departments. A similar rule was issued by the New York Stock Exchange (NYSE) in Rule 472 Communications with the Public. As documented in Lee et al. (2014) these rules were approved in May 2002 and implemented through November of 2002.

The Global Research Analyst Settlement was published in December of 2002 and enforced in April of 2003. This global settlement attempted to resolve conflicts of interest at brokerage firms between investment banking and securities research by separating these functions (SEC (2002)). The final regulatory change for analysts was the implementation in April of 2003 of the Regulation Analyst Certification (SEC (2003)). This required that analysts indicate in their research reports whether the research reported accurately reflects their personal views. In addition, it required that analysts disclose whether they had received compensation related to their recommendations. 


\subsection{Hypotheses}

Because of the close proximity of the effective dates for the analyst rules and the implementation of Reg FD and SOX, we combine our testing of these regulatory changes. This leads to our first hypothesis (stated in the null):

H1: Regulatory changes have not significantly affected the relationship between earnings (and components of earnings) and stock returns.

Overall, the prior research finds that discretionary accruals decreased post-SOX. This suggests that the relationship between earnings and stock returns should have been strengthened post-SOX and leads to our second hypothesis (stated in the null):

H2: Regulatory changes have not significantly affected the persistence of earnings and earnings components (cash flows and accruals).

The rest of the study is organized as follows. Section 2 describes our data and methodology. The main empirical results are presented in Section 3 and Section 4 contains our conclusions.

\section{Sample and Methodology}

Our sample includes all December 31 fiscal year-end firms that are listed on NYSE, AMEX or NASDAQ during the period 1988 through 2012. We restrict our sample to those firms from COMPUSTAT (annual) with positive total assets (AT) for which we can calculate changes in earnings before extraordinary items as reported on the income statement (IB) and changes in cash flows from operations as reported on the cash flow statement (OANCF) and for which we can identify their earnings announcement date (we use quarterly COMPUSTAT to get the report date of the fourth quarter earnings). We define our accruals measure as the difference between earnings and cash flows from operations. We further restrict our sample to those firms for which we can find the corresponding monthly return data in CRSP. Abnormal (cumulative) monthly returns for each firm are calculated as (cumulative) size-adjusted returns, by subtracting the corresponding return of the CRSP size-decile portfolio to which the firm belongs. (Note 3)

We examine the change in the strength of the relation between earnings and returns from the pre- to the post-regulation periods. Following Lee et al. (2014), we consider that relevant regulation was passed during the period from September 2000 to May 2003; therefore, we define the pre- and post-regulation periods from January 1988-September 2000 and May 2003-December 2012 respectively. Table 1 presents the descriptive statistics separately for each of our two subsamples of interest. 
Table 1. Descriptive Statistics

\begin{tabular}{|c|c|c|c|c|c|}
\hline \multicolumn{6}{|c|}{ Panel A: Pre-Regulation Sample Period (1988.01 -2000.09) $(\mathrm{N}=26,657)$} \\
\hline & Mean & $\underline{\text { Std. Dev }}$ & $\underline{1^{\text {st }} \text { Quartile }}$ & Median & $\underline{3^{\text {rd }} \text { Quartile }}$ \\
\hline Market Cap (\$MM) & 1587.871 & 11378.463 & 19.579 & 113.483 & 618.308 \\
\hline Returns & 0.163 & 0.657 & -0.210 & 0.057 & 0.340 \\
\hline Abnormal Ret & -0.013 & 0.531 & -0.326 & -0.087 & 0.152 \\
\hline Earnings (\$MM) & 74.688 & 416.639 & -0.844 & 5.001 & 31.025 \\
\hline Earnings Chg (\$MM) & 5.471 & 229.495 & -3.139 & 0.778 & 7.136 \\
\hline Total Assets (\$MM) & 2501.275 & 14724.720 & 47.446 & 182.389 & 865.692 \\
\hline Cash Flows (\$MM) & 166.749 & 838.162 & 0.460 & 10.435 & 65.647 \\
\hline Cash Flow Chg(\$MM) & 11.294 & 349.211 & -4.131 & 0.861 & 10.711 \\
\hline Accruals (\$MM) & -92.335 & 558.760 & -35.902 & -5.859 & -0.147 \\
\hline Accrual Chg (\$MM) & -5.820 & 405.287 & -10.000 & -0.553 & 5.464 \\
\hline \multicolumn{6}{|c|}{ Panel B: Post-Regulation Sample Period (2003.05-2012.12) $(\mathrm{N}=26,149)$} \\
\hline & Mean & $\underline{\text { Std. Dev }}$ & $\underline{1^{\text {st }} \text { Quartile }}$ & $\underline{\text { Median }}$ & $\underline{3^{\text {rd }} \text { Quartile }}$ \\
\hline Market Cap (\$MM) & 7151.091 & 29302.560 & 71.219 & 634.016 & 3708.187 \\
\hline Returns & 0.195 & 0.766 & -0.229 & 0.068 & 0.391 \\
\hline Abnormal Ret & 0.008 & 0.474 & -0.264 & -0.052 & 0.178 \\
\hline Earnings (\$MM) & 160.147 & 1543.029 & -4.643 & 10.100 & 71.028 \\
\hline Earnings Chg (\$MM) & 15.869 & 1354.452 & -7.175 & 1.569 & 19.019 \\
\hline Total Assets (\$MM) & 8650.232 & 73117.925 & 146.244 & 651.920 & 2533.266 \\
\hline Cash Flows (\$MM) & 387.784 & 2820.977 & 2.547 & 31.155 & 161.496 \\
\hline Cash Flow Chg(\$MM) & 33.614 & 2770.417 & -8.760 & 1.555 & 22.893 \\
\hline Accruals (\$MM) & -225.011 & 2503.062 & -93.950 & -17.904 & -2.121 \\
\hline Accrual Chg (\$MM) & -16.984 & 2994.120 & -20.523 & -0.586 & 14.700 \\
\hline
\end{tabular}

The samples for each one of the panels contain all firm-year observations for calendar year firms traded on NYSE, AMEX and NASDAQ with relevant data available in COMPUSTAT and CRSP as follows: Market Cap is the number of shares outstanding times market price per share as of the end of the fiscal year from COMPUSTAT (cshtr_f* prcc_f); Returns are daily returns cumulated over the 12 months prior to and including the month of the $4^{\text {th }}$ quarter earnings announcement. Following NW, we define month as 21 trading days and the month of the earnings announcement includes the date of the announcement plus the ten days before and the ten days after the announcement of earnings; Abnormal Ret are the cumulative raw returns described above less the cumulative returns over the same period to the size decile to which the firm belongs; Earnings are the income before extraordinary items, as reported on the income statement (IB); Earnings Chg are current year earnings minus prior year earnings; Total Assets are yotal assets reported on the balance sheet (AT); Cash Flows are operating cash flows as reported on the Cash Flow Statement (OANCF). In the following tests, we used a scaled version of this variable (where we scale OANCF by the lagged total assets or by sales, alternatively); Cash Flow Chg are current year cash flows minus prior year cash flows; Accruals are the difference between earnings and cash flows (a scaled version of this variable - by either lagged assets or sales - is used in some of the following tests); Accruals Chg are current year accruals minus prior year accruals.

As presented in Panel A of Table 1, our pre-regulation period sample contains 26,657 firm-year observations that meet our criteria. The characteristics of this sample are comparable to the sample analyzed by Nichols and Wahlen (2004). Similar to the firms in their sample, the firms in our pre-regulation period sample vary widely in size, are profitable (in terms of Earnings) and increasing in market capitalization (in terms of Returns). The average firm in our sample has a market capitalization of $\$ 1,587$ million, total assets of $\$ 2,501$ million and earnings of $\$ 74.7$ million (compared to \$1,946 million, \$2,795 million and \$69.9 million, respectively, from Nichols \& Wahlen, 2004). 
The same sample selection process results in a sample of 26,149 firm-year observations for the post-regulation period of 2003 through 2012. Descriptive statistics for this period are presented in Panel B of Table 1. In comparison to the pre-regulation period, the means and most quartile points are much larger for Market Capital, Earnings, Earnings Changes, Total Assets, Cash Flows and Cash Flow Changes, while the means and quartile points for the variables Returns and Abnormal Returns for this period of time are fairly comparable to the estimates from the initial period. In contrast, the average accruals are more negative in the recent period relative to the pre-regulation sample, indicating that the increase in earnings in the recent period is most likely driven by the cash flow component.

Our analysis identifies the importance of earnings information for market returns and the evolution of this relation through time. Our approach involves using the methodology presented by Nichols and Wahlen, 2004 and Ball and Brown, 1968 for our pre- and post-regulation periods and then testing whether there are any economically and/or statistically significant differences between the two time periods. Specifically, we group firms into two portfolios based on the sign of the firm's annual earnings changes (positive or negative). Then we calculate the cumulative abnormal returns of each portfolio in event time relative the earnings announcement month, beginning 11 months prior to and continuing through 6 months after the month in which firms announce their earnings. We then calculate the difference in abnormal returns between these portfolios and test whether this difference is statistically significant from zero. The results are summarized by averaging the cumulative returns across all event months, and interpret the difference in cumulative abnormal returns as the strength of the return effect of earnings changes. To investigate the source of this relationship, we decompose earnings into cash flow from operations and accruals and repeat the exercise described above, so that we can compare the association between earnings changes and returns with the association between cash flow changes (and accrual changes, respectively) and returns.

Since our objective is to study this association during our two sample periods, we repeat the analysis outlined above separately within each sample. We then compare the strength of the relation between earnings changes (and the cash flow and accruals components changes, respectively) and returns across the two subsamples, by testing for significant differences in the abnormal returns differentials. For example, a statistical increase in the average difference in abnormal returns between firms with positive and negative earnings changes for the recent period relative to the pre-regulation period would indicate that the relation between earnings changes and returns is stronger during this period, while a decrease in the magnitude of the average abnormal return difference would indicate a weakened relationship.

To identify potential drivers of these differences, we also estimate and compare average persistence parameters for the pre- and post- regulation periods. As briefly discussed in the previous sections, a change in the quality/persistence of earnings numbers could be the main force behind a shift in the importance of earnings for market participants. Therefore, we calculate persistence coefficients for earnings and their components for each subsample and the overall period and look for significant changes in these coefficients. For each firm and each sample, we follow the simple model specification described in Dechow et al., 2010 to estimate earnings persistence:

$$
\text { Earning }_{t+1}=\alpha+\beta \text { Earnings }_{t}+\varepsilon_{t}
$$

In the equation above we use earnings scaled by sales (Note 4) and interpret $\beta$ as a measure of persistence (a higher $\beta$ implies that the earnings stream is more persistent). We estimate earnings persistence for each firm using all the available data during each period of interest and report average earnings persistence across each subsample. (Note 5) We further decompose total earnings into components (following the methodology originally proposed by Sloan, 1996) and estimate the persistence of cash flows and accruals separately, as follows:

$$
\text { Earnings }_{t+1}=\alpha+\beta_{1} \text { CF }_{t}+\beta_{2} \text { Accrual }_{t}+\varepsilon_{t}
$$

All of the variables in equation (2) are scaled by sales. We estimate equation (2) for each firm in each sample using all the available years for that respective sample and consider $\beta_{1}$ and $\beta_{2}$ persistence coefficients for cash flows and accruals, respectively.

As previously discussed, the observed relationship between earnings and returns is likely to reflect the net result of a combination of different dynamic factors, including market efficiency and the asset pricing process. Our interpretation of the results is that the passage of the discussed regulation has caused a weakened relation between earnings and returns. In order to substantiate this claim, we present two additional type of tests: (1) we study a control group of international firms that were not subject to the passage of the aforementioned regulation and (2) we perform a more thorough regression analysis to investigate whether the strength of the relation between the two variables has changed through time. 
To show that the post-regulation decrease in the strength of the relation between earnings and returns is not due to an unknown factor specific to that particular time period, we compare changes in this relationship for firms listed in the United States (US) to European listed firms. Because European listed firms were not affected by the regulations in the US, they serve as a control sample for the US firms. Following Lee et al (2014), we construct a European sample based on firms listed in 15 countries (Austria, Belgium, Denmark, Finland, France, Germany, Greece, Ireland, Italy, Netherlands, Norway, Spain, Sweden, Switzerland, and UK). We use Compustat Global to obtain the necessary accounting and return data for these firms and follow the methodology employed for our US sample as close as possible. Our final European sample covers the period from 1995 to 2012 and has a total of 34,425 firm-year observations over all the countries considered. Within this sample, we repeat the Nichols and Wahlen (2004) methodology for the pre- and post US - regulation periods and investigate the changes between the two samples. Finding no significant difference in the European firm sample would support our claim that the passing of the regulation is (at least partly) responsible for the weakened relationship between earnings and returns in the US.

Additionally, to provide a more rigorous test of the significance for the decline in the strength of the earnings/return relationship in the post-regulation period, we adopt a regression approach. Specifically, to test whether the relation with changes in earnings is significantly different in the post-regulation period, we run a regression which takes the following form:

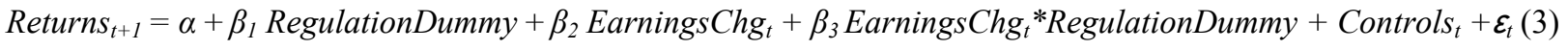

where RegulationDummy takes value 1 for years after 2003. We run equation (3) above at pooled level, and cluster the errors in two dimensions to control for firm and year fixed effects. A significant $\beta_{3}$ coefficient on the interaction term would indicate a significant change in the relation between returns and changes in earnings in the post-regulation period. Controls include size and book-to-market. To investigate the relation between returns and accruals/cash flows, we replace changes in earnings in equation (3) above with changes in accruals and/or changes in cash flows. The results obtained using the methodology described above are presented in the following section.

\section{Main Empirical Results}

\subsection{The Association between Earnings Changes and Cumulative Returns}

We start by assessing whether the sign of change in annual earnings is associated with the sign of abnormal annual stock returns and whether this association has remained stable during our post-regulation period of May 2003-2012 relative to our pre-regulation period of January 1988-September 2000. Based on the results presented by Nichols and Wahlen, 2004 we expect that during the pre-regulation period, firms with earnings increases (decreases) experience positive (negative) abnormal returns. We follow the methodology of the aforementioned paper and group all sample firms each year into two portfolios based on the sign of their earnings changes. We then cumulate the returns of these portfolios in event time relative to the announcement date, starting eleven months prior to and continuing six months after the event time. Finally, we average the abnormal returns across event times and report the cumulative abnormal returns for firms with positive and negative earnings changes, as well as the differences in abnormal returns between these portfolios. Results are presented in Table 2 Panel A for the pre-regulation period and in Panel B for the post-regulation period. Panel $\mathrm{C}$ summarizes the change from the pre- period to the post-regulation period. 
Table 2. The Association between Annual Earnings Changes and Cumulative Abnormal Returns

\begin{tabular}{|c|c|c|c|c|c|c|c|}
\hline & \multicolumn{3}{|c|}{$\begin{array}{l}\text { Panel A: Pre-Regulation Period } \\
\quad(1988.12-2000.09)\end{array}$} & \multicolumn{3}{|c|}{$\begin{array}{l}\text { Panel B: Post-Regulation Period } \\
\quad(2003.05-2012.12)\end{array}$} & \multirow[t]{2}{*}{$\begin{array}{c}\text { Panel C: } \\
\text { Changes Post-Pre }\end{array}$} \\
\hline & \multicolumn{3}{|c|}{ Cumulative Abnormal } & \multicolumn{3}{|c|}{ Cumulative Abnormal } & \\
\hline Months & \multicolumn{3}{|c|}{ Returns for Firms with: } & \multicolumn{3}{|c|}{ Returns for Firms with: } & Changes in Diff \\
\hline Relative & Pos. & Neg. & & Pos. & Neg. & & \\
\hline to Earn. & Earnings & Earnings & $\underline{\text { Diff. }}$ & Earnings & Earnings & $\underline{\text { Diff. }}$ & $\underline{\Delta \text { Diff. }}$ \\
\hline$\underline{\text { Ann. }}$. & Changes & $\underline{\text { Changes }}$ & & $\underline{\text { Changes }}$ & $\underline{\text { Changes }}$ & & \\
\hline-11 & 0.012 & -0.012 & $0.024 * * *$ & 0.014 & -0.005 & $0.019 * * *$ & -0.005 \\
\hline-10 & 0.029 & -0.028 & $0.057 * * *$ & 0.033 & -0.014 & $0.050 * * *$ & -0.007 \\
\hline-9 & 0.043 & -0.038 & $0.081 * * *$ & 0.046 & -0.027 & $0.075^{* * *}$ & -0.006 \\
\hline-8 & 0.053 & -0.063 & $0.114 * * *$ & 0.053 & -0.043 & $0.097 * * *$ & -0.017 \\
\hline-7 & 0.065 & -0.089 & $0.151 * * *$ & 0.063 & -0.064 & $0.129 * * *$ & $-0.023^{*}$ \\
\hline-6 & 0.074 & -0.104 & $0.174 * * *$ & 0.070 & -0.069 & $0.143 * * *$ & $-0.031 * *$ \\
\hline-5 & 0.078 & -0.124 & $0.196^{* * *}$ & 0.072 & -0.077 & $0.151^{* * *}$ & $-0.045^{* * *}$ \\
\hline-4 & 0.080 & -0.148 & $0.223 * * *$ & 0.080 & -0.094 & $0.175 * * *$ & $-0.047 * * *$ \\
\hline-3 & 0.082 & -0.162 & $0.241 * * *$ & 0.089 & -0.103 & $0.193 * * *$ & $-0.047 * *$ \\
\hline-2 & 0.083 & -0.173 & $0.254 * * *$ & 0.093 & -0.105 & $0.199 * * *$ & $-0.055^{* * *}$ \\
\hline-1 & 0.084 & -0.177 & $0.261 * * *$ & 0.093 & -0.113 & $0.204 * * *$ & $-0.056^{* *}$ \\
\hline 0 & 0.092 & -0.184 & $0.276^{* * *}$ & 0.100 & -0.124 & $0.221 * * *$ & $-0.055^{* *}$ \\
\hline 1 & 0.096 & -0.184 & $0.281 * * *$ & 0.105 & -0.124 & $0.225^{* * *}$ & $-0.055 * *$ \\
\hline 2 & 0.101 & -0.184 & $0.286^{* * *}$ & 0.106 & -0.121 & $0.222 * * *$ & $-0.064 * * *$ \\
\hline 3 & 0.106 & -0.183 & $0.290 * * *$ & 0.104 & -0.124 & $0.222 * * *$ & $-0.068 * * *$ \\
\hline 4 & 0.104 & -0.185 & $0.291 * * *$ & 0.107 & -0.128 & $0.228 * * *$ & $-0.063 * * *$ \\
\hline 5 & 0.102 & -0.188 & $0.289 * * *$ & 0.102 & -0.132 & $0.226^{* * *}$ & $-0.063 * * *$ \\
\hline 6 & 0.102 & -0.188 & $0.289 * * *$ & 0.101 & -0.131 & $0.224 * * *$ & $-0.065 * * *$ \\
\hline
\end{tabular}

We form portfolios every year based on positive and negative earnings changes (scaled by lagged total assets) for each period, where earnings are defined as described in Table 1. Cumulative abnormal returns are calculated as cumulative raw returns minus the cumulative return to the size decile portfolio to which the firm belongs. The cumulation period starts 11 months before the earnings announcement month. Panel A presents the results for the period pre-regulation, while Panel B repeats the test for the post-regulation period. Panel C examines if the differences between the cumulative abnormal returns for firms with positive and negative earnings changes have changed in the post-regulation period relative to the pre-regulation period. $*, * *, * *$ denote statistical significance at the $10 \%, 5 \%$ and $1 \%$ level, respectively.

The results for the pre-regulation sample (Panel A) are qualitatively similar to those presented by Nichols and Wahlen (2004) for the same time period. Specifically, firms with positive (negative) annual earnings changes have sizable positive (negative) cumulative returns - the sign of the change in earnings is associated with an average difference of 27.6 percent in abnormal annual returns (compared to 35.6 percent reported by the aforementioned paper) and this difference is statistically significant at the $1 \%$ level.

By comparison, Panel B reports a statistically significant difference in annual abnormal returns of 22.1 percent over the post-regulation period. While this difference in abnormal returns has not dropped to 16.8 percent reported by Ball and Brown, 1968 over their sample period of 1957 through 1965, it has definitely decreased relative to the pre-regulation period. Our results indicate that the return implications of earnings changes have decreased substantially in the years after the regulatory changes. Panel $\mathrm{C}$ of Table 2 shows that the difference between the pre-regulation period and the post-regulation period has declined significantly. 
Overall, two conclusions can be drawn from this set of results. One is that the information contained in earnings continues to be relevant for market participants. However, the second conclusion is that the strength of the relation between earnings and returns seems to be significantly diminished after the regulatory changes.

\subsection{The Source of Earnings Changes and Cumulative Returns}

Given that earnings are a combination of a firm's cash flows from operations and accounting accruals, the next logical question is whether the usefulness of earnings numbers for market participants is solely driven by the cash flow information or whether the information contained in accounting accruals is also relevant. Nichols and Wahlen (2004) document that annual earnings changes contain more value-relevant information than changes in cash flows from operations, thus highlighting the importance of the information contained in accounting accruals. The empirical question is whether their results still hold, and whether the relative information content of accruals and cash flows has remained stable in the more recent period after the regulatory changes.

In this section, we separate the effect of cash flows and accruals by documenting differences in abnormal returns of portfolios sorted by changes in each component of earnings. This allows us to isolate how important is the source of earnings changes for market participants. In Table 3, we present the results of our comparison of the market response to firms reporting positive cash flow changes to the market response to those reporting negative changes.

Table 3. The Association between Annual Cash Flow Changes and Cumulative Abnormal Returns

\begin{tabular}{|c|c|c|c|c|c|c|c|}
\hline & \multicolumn{3}{|c|}{$\begin{array}{l}\text { Panel A: Pre-Regulation Period } \\
\quad(1988.12-2000.09) \\
\end{array}$} & \multicolumn{3}{|c|}{$\begin{array}{l}\text { Panel B: Post-Regulation Period } \\
\quad(2003.05-2012.12) \\
\end{array}$} & \multirow[t]{2}{*}{$\begin{array}{c}\text { Panel C: } \\
\text { Changes Post-Pre }\end{array}$} \\
\hline & \multicolumn{3}{|c|}{ Cumulative Abnormal } & \multicolumn{3}{|c|}{ Cumulative Abnormal } & \\
\hline Months & \multicolumn{3}{|c|}{ Returns for Firms with: } & \multicolumn{3}{|c|}{ Returns for Firms with: } & Changes in Diff \\
\hline Relative & Pos. & Neg. & & Pos. & Neg. & & \\
\hline to Earn. & Earnings & Earnings & Diff. & Earnings & Earnings & Diff. & $\Delta$ Diff. \\
\hline$\underline{\text { Ann. }}$. & $\underline{\text { Changes }}$ & $\underline{\text { Changes }}$ & & $\underline{\text { Changes }}$ & $\underline{\text { Changes }}$ & & \\
\hline-11 & 0.005 & -0.002 & $0.007 * * *$ & 0.008 & 0.004 & 0.005 & -0.002 \\
\hline-10 & 0.014 & -0.006 & $0.019 * * *$ & 0.022 & 0.003 & $0.021 * * *$ & 0.002 \\
\hline-9 & 0.021 & -0.006 & $0.026 * * *$ & 0.032 & -0.004 & $0.038 * * *$ & $0.012 * *$ \\
\hline-8 & 0.023 & -0.017 & $0.038 * * *$ & 0.036 & -0.015 & $0.053 * * *$ & $0.015^{* *}$ \\
\hline-7 & 0.026 & -0.029 & $0.051 * * *$ & 0.039 & -0.026 & $0.068 * * *$ & $0.017 * *$ \\
\hline-6 & 0.027 & -0.034 & $0.057 * * *$ & 0.044 & -0.028 & $0.075^{* * *}$ & $0.018^{*}$ \\
\hline-5 & 0.027 & -0.045 & $0.067 * * *$ & 0.044 & -0.034 & $0.080 * * *$ & 0.014 \\
\hline-4 & 0.023 & -0.061 & $0.079 * * *$ & 0.050 & -0.046 & $0.098 * * *$ & $0.018^{*}$ \\
\hline-3 & 0.022 & -0.071 & $0.089 * * *$ & 0.057 & -0.052 & $0.111^{* * *}$ & $0.021^{* *}$ \\
\hline-2 & 0.023 & -0.080 & $0.098 * * *$ & 0.060 & -0.051 & $0.113 * * *$ & $0.015^{*}$ \\
\hline-1 & 0.022 & -0.081 & $0.099 * * *$ & 0.056 & -0.054 & $0.112 * * *$ & 0.013 \\
\hline 0 & 0.027 & -0.084 & $0.108 * * *$ & 0.060 & -0.061 & $0.123 * * *$ & 0.015 \\
\hline 1 & 0.032 & -0.084 & $0.113 * * *$ & 0.065 & -0.060 & $0.125 * * *$ & 0.013 \\
\hline 2 & 0.038 & -0.086 & $0.120 * * *$ & 0.067 & -0.059 & $0.127 * * *$ & 0.007 \\
\hline 3 & 0.045 & -0.087 & $0.126^{* * *}$ & 0.066 & -0.062 & $0.129 * * *$ & 0.002 \\
\hline 4 & 0.045 & -0.092 & $0.132 * * *$ & 0.067 & -0.063 & $0.130 * * *$ & -0.002 \\
\hline 5 & 0.043 & -0.095 & $0.133 * * *$ & 0.060 & -0.066 & $0.126^{* * *}$ & -0.007 \\
\hline 6 & 0.043 & -0.095 & $0.136 * * *$ & 0.060 & -0.065 & $0.125 * * *$ & -0.011 \\
\hline
\end{tabular}

We form portfolios every year based on positive and negative cash flow changes (scaled by lagged total assets) for each period, where cash flows are defined as described in Table 1. Cumulative abnormal returns are calculated as cumulative raw returns minus the cumulative return to the size decile portfolio to which the firm belongs. The cumulation period starts 11 months before the earnings announcement month. Panel A presents the results for the period pre-regulation, while Panel B repeats the test for the post-regulation period. Panel C examines if the 
differences between the cumulative abnormal returns for firms with positive and negative cash flow changes have changed in the post-regulation period relative to the pre-regulation period. $*, * *, * *$ denote statistical significance at the $10 \%, 5 \%$ and $1 \%$ level, respectively.

Similar to Nichols and Wahlen's results, our analysis indicates that the sign of the change in operating cash flow is significantly associated with the cumulative abnormal returns for the pre-regulation period (Panel A). Firms with positive cash flow changes have on average 10.8 percent higher abnormal returns than their negative cash flow changes counterparts. Interestingly, the market response to changes in operating cash flows is stable across the two time periods. Panel B shows that for the post-regulation period, the same strategy produces 12.3 percent annual abnormal returns. This is in contrast to our finding that the market response to earnings was dampened in the post-regulation period.

Combining the results reported in Table 2 for earnings changes with the cash flow changes from Table 3 leads us to draw the following conclusions. While the overall shape of the relation between earnings/cash flow changes and returns remains similar during the pre- and post-regulation periods, the magnitude of the returns for positive earnings changes is smaller in the post-regulation period. Also, the difference between abnormal returns for positive and negative earnings changes firms is smaller during the later period, while the difference between firms with positive cash flow changes and negative cash flow changes remains relatively unchanged. This suggests that annual earnings changes contain more value-relevant information than changes in cash flows from operations.

Overall, these results show that the information content of cash flows for market participants remains relatively stable after the passage of the various regulatory changes and thus is not the driving force behind the diminishing relation between earnings and returns. The obvious question then is whether accruals (the other component of earnings) are less relevant in the later period. Table 4 presents this analysis.

Table 4. The Association between Annual Accrual Changes and Cumulative Abnormal Returns

\begin{tabular}{|c|c|c|c|c|c|c|c|}
\hline & \multicolumn{3}{|c|}{$\begin{array}{l}\text { Panel A: Pre-Regulation Period } \\
\quad(1988.12-2000.09)\end{array}$} & \multicolumn{3}{|c|}{$\begin{array}{l}\text { Panel B: Post-Regulation Period } \\
\quad(2003.05-2012.12)\end{array}$} & $\begin{array}{c}\text { Panel C: } \\
\text { Changes Post-Pre }\end{array}$ \\
\hline Months & $\begin{array}{l}\text { Cumulativ } \\
\text { Returns for }\end{array}$ & $\begin{array}{l}\text { Abnormal } \\
\text { Firms with: }\end{array}$ & & $\begin{array}{l}\text { Cumulati } \\
\text { Returns fo }\end{array}$ & $\begin{array}{l}\text { Abnormal } \\
\text { Firms with: }\end{array}$ & & Changes in Diff \\
\hline $\begin{array}{l}\text { Relative } \\
\text { to Earn. } \\
\text { Ann. }\end{array}$ & $\begin{array}{l}\text { Pos. } \\
\text { Earnings } \\
\text { Changes } \\
\end{array}$ & $\begin{array}{l}\text { Neg. } \\
\text { Earnings } \\
\text { Changes }\end{array}$ & $\underline{\text { Diff. }}$ & $\begin{array}{l}\text { Pos. } \\
\text { Earnings } \\
\text { Changes } \\
\end{array}$ & $\begin{array}{l}\text { Neg. } \\
\text { Earnings } \\
\text { Changes }\end{array}$ & $\underline{\text { Diff. }}$ & $\Delta$ Diff. \\
\hline-11 & 0.007 & -0.002 & $0.009 * * *$ & 0.011 & 0.001 & $0.010 * *$ & 0.001 \\
\hline-10 & 0.016 & -0.003 & $0.020 * * *$ & 0.026 & 0.003 & $0.022 * * *$ & 0.002 \\
\hline-9 & 0.026 & -0.003 & $0.029 * * *$ & 0.032 & 0.001 & $0.029 * *$ & 0.001 \\
\hline-8 & 0.030 & -0.014 & $0.042 * * *$ & 0.032 & -0.003 & $0.033 * * *$ & -0.009 \\
\hline-7 & 0.031 & -0.022 & $0.051 * * *$ & 0.035 & -0.011 & $0.043 * * *$ & -0.008 \\
\hline-6 & 0.035 & -0.027 & $0.059 * * *$ & 0.037 & -0.010 & $0.045^{* *}$ & -0.014 \\
\hline-5 & 0.033 & -0.035 & $0.066^{* * *}$ & 0.037 & -0.014 & $0.048 * *$ & -0.018 \\
\hline-4 & 0.026 & -0.046 & $0.070 * * *$ & 0.037 & -0.018 & $0.052 * *$ & -0.018 \\
\hline-3 & 0.022 & -0.051 & $0.070 * * *$ & 0.040 & -0.018 & $0.055^{* * *}$ & -0.016 \\
\hline-2 & 0.018 & -0.054 & $0.071 * * *$ & 0.042 & -0.017 & $0.056 * * *$ & -0.016 \\
\hline-1 & 0.018 & -0.056 & $0.075^{* * *}$ & 0.044 & -0.024 & $0.063 * * *$ & -0.012 \\
\hline 0 & 0.022 & -0.056 & $0.077 * * *$ & 0.045 & -0.027 & $0.065 * * *$ & -0.013 \\
\hline 1 & 0.023 & -0.053 & $0.077 * * *$ & 0.048 & -0.024 & $0.063 * * *$ & -0.014 \\
\hline 2 & 0.025 & -0.049 & $0.074 * * *$ & 0.047 & -0.020 & $0.059 * * *$ & -0.015 \\
\hline 3 & 0.027 & -0.044 & $0.070 * * *$ & 0.043 & -0.021 & $0.056^{* *}$ & -0.014 \\
\hline 4 & 0.022 & -0.044 & $0.065^{* * *}$ & 0.045 & -0.022 & $0.057 * * *$ & -0.007 \\
\hline 5 & 0.019 & -0.046 & $0.062 * * *$ & 0.040 & -0.027 & $0.057 * * *$ & -0.005 \\
\hline 6 & 0.017 & -0.044 & $0.057 * * *$ & 0.039 & -0.026 & $0.056 * * *$ & -0.002 \\
\hline
\end{tabular}


We form portfolios every year based on positive and negative accruals changes (scaled by lagged total assets) for each period, where accruals are defined as described in Table 1. Cumulative abnormal returns are calculated as cumulative raw returns minus the cumulative return to the size decile portfolio to which the firm belongs. The accumulation period starts 11 months before the earnings announcement month. Panel A presents the results for the period pre-regulation, while Panel B repeats the test for the post-regulation period. Panel C examines if the difference between the cumulative abnormal returns for firms with positive and negative accruals changes have changed in the post-regulation period relative to the pre-regulation period. $*, * *, * *$ denote statistical significance at the $10 \%, 5 \%$ and $1 \%$ level, respectively.

As defined in Table 1, accrual changes were measured as the difference between earnings and operating cash flows. The overall results indicate that positive (negative) accrual changes are associated with positive (negative) cumulative abnormal returns, supporting the value relevance of accounting accruals for market participants. Similar to the results from the analysis of cash flow changes, the abnormal returns for firms with positive and negative changes in accruals from each of the subsamples are fairly similar. Panel A reports that during the pre-regulation time frame the difference in abnormal returns averages 7.7 percent, relative to 6.5 percent during the post-regulation period reported in Panel B. As indicated in Panel C, the differences in abnormal returns between the two periods are not significantly different.

Taken together, the results presented in Tables 3 and 4 indicate that the market reacts to the information contained in both components of earnings (cash flows and accruals). While the magnitude of the market response to operating cash flow changes is larger than the response to accrual changes, (Note 6) they both result in statistically significant market return movements, justifying the conclusion that earnings contain more value-relevant information than cash flows. Furthermore, although the overall relation between earnings and returns seems to have weakened in the more recent post-regulation period (Table 2), the information content of both accruals and cash flows remains relatively stable across sub-periods (Tables 3 and 4, respectively).

\subsection{The Persistence of the Relation between Earnings and Returns}

Earnings persistence is also an important determinant of the relation between earnings and returns, since more persistent earnings are likely to be more informative and therefore it is more likely that returns would react to this information. One possibility is that the magnitude of earnings changes is significantly different during the post-regulatory period which would justify the change in the strength of the relation between earnings and returns. Table 1 does provide some support to this argument. During the pre-regulation period the average earnings changes are 5.471 million, while during the post-regulation period this average becomes 15.869 million. An alternative possibility, given that the strength of the relation between components of earnings (i.e. cash flows and accruals) has not significantly changed, it is likely that the return differences are not solely driven by the differences in the magnitude of the earnings changes. The diminished market reaction to earnings changes in the post-regulation period could also be the result of an overall decreased quality of earnings manifested in decreased persistence. We formally investigate whether the persistence of earnings and earnings components is significantly different in the later period relative to the pre-regulation period. Specifically, we calculate persistence coefficients for each subsample and test whether the average persistence has significantly changed in the later period. The results are presented in Table 5 . 
Table 5. Changes in Persistence Characteristics

Panel A: Characteristics of persistence parameters by subperiods

\begin{tabular}{|c|c|c|c|c|c|c|c|c|c|}
\hline & \multicolumn{3}{|c|}{ Earnings Persistence } & \multicolumn{3}{|c|}{ Cash Flow Persistence } & \multicolumn{3}{|c|}{ Accrual Persistence } \\
\hline & Pre-Reg. & Post-Reg. & $\underline{\text { Diff Post-Pre }}$ & Pre-Reg. & Post-Reg. & $\underline{\text { Diff Post-Pre }}$ & Pre-Reg. & Post-Reg. & Diff Post-Pre \\
\hline Mean & 0.368 & 0.297 & $-0.070 * * *$ & 0.425 & 0.386 & $-0.039 * * *$ & 0.312 & 0.247 & $-0.065 * * *$ \\
\hline Median & 0.353 & 0.286 & $(15.89)$ & 0.437 & 0.387 & (4.39) & 0.303 & 0.240 & $(9.29)$ \\
\hline StDev & 0.421 & 0.356 & & 0.650 & 0.812 & & 0.565 & 0.597 & \\
\hline $\mathrm{N}$ & 15989 & 15129 & & 13913 & 13446 & & 13913 & 13446 & \\
\hline \multicolumn{10}{|c|}{ Panel B: Persistence Parameters for firm-years with positive earnings changes } \\
\hline & \multicolumn{3}{|c|}{ Earnings Persistence } & \multicolumn{3}{|c|}{ Cash Flow Persistence } & \multicolumn{3}{|c|}{ Accrual Persistence } \\
\hline & Pre-Reg. & Post-Reg. & $\underline{\text { Diff Post-Pre }}$ & Pre-Reg. & Post-Reg. & Diff Post-Pre & Pre-Reg. & Post-Reg. & Diff Post-Pre \\
\hline Mean & 0.376 & 0.306 & $-0.070 * * *$ & 0.432 & 0.384 & $-0.048 * * *$ & 0.317 & 0.257 & $-0.060 * * *$ \\
\hline Median & 0.369 & 0.298 & $(12.67)$ & 0.451 & 0.389 & $(4.39)$ & 0.321 & 0.255 & $(7.02)$ \\
\hline StDev & 0.410 & 0.351 & & 0.626 & 0.792 & & 0.538 & 0.566 & \\
\hline $\mathrm{N}$ & 9741 & 9198 & & 8572 & 8262 & & 8572 & 8262 & \\
\hline \multicolumn{10}{|c|}{ Panel C: Persistence Parameters for firm-years with negative earnings changes } \\
\hline & \multicolumn{3}{|c|}{ Earnings Persistence } & \multicolumn{3}{|c|}{ Cash Flow Persistence } & \multicolumn{3}{|c|}{ Accrual Persistence } \\
\hline & Pre-Reg. & Post-Reg. & $\underline{\text { Diff Post-Pre }}$ & Pre-Reg. & Post-Reg. & Diff Post-Pre & Pre-Reg. & Post-Reg. & Diff Post-Pre \\
\hline Mean & 0.354 & 0.284 & $-0.070 * * *$ & 0.413 & 0.389 & -0.024 & 0.304 & 0.230 & $-0.074 * * *$ \\
\hline Median & 0.331 & 0.270 & (9.63) & 0.411 & 0.386 & $(1.61)$ & 0.280 & 0.215 & $(6.09)$ \\
\hline StDev & 0.439 & 0.361 & & 0.688 & 0.841 & & 0.605 & 0.644 & \\
\hline $\mathrm{N}$ & 6248 & 5931 & & 5341 & 5184 & & 5341 & 5184 & \\
\hline
\end{tabular}

Following Richardson et al (2005) and Sloan (1996), we decompose earnings into cash flows and accruals and estimate overall earnings as well as each component's persistence at individual firm level as described in equations (1) and (2) in the main text. We estimate equations (1) and (2) in sample for each of the respective panels and exclude firms without at least 6 consecutive observations. The table above presents the descriptive statistics of the persistence parameters calculated as described above for each subsample as well as the overall sample, along with the differences in means between the two subsample periods. The pre-regulation period (Pre-Reg.) corresponds to years 1988 to 2000; the post-regulation period (Post-Reg.) corresponds to years 2003 to 2012. The numbers in parentheses are $t$-statistics. ${ }^{*}, * *, * *$ denote statistical significance at the $10 \%, 5 \%$ and $1 \%$ level, respectively.

Panel A of Table 5 presents the descriptive statistics for persistence parameters of earnings, cash flows and accruals by time periods, along with a test of the statistical difference in average persistence parameters between the two samples of interest. The results indicate that the mean persistence of earnings, cash flow, and accruals is significantly smaller in the post-regulation period compared to the pre-regulation period. While the persistence of cash flows does significantly decline, the magnitude of the decline in accruals persistence is much larger and seems to drive the decline in the persistence of earnings. Nichols and Wahlen (2004) argue that the difference in abnormal returns across high and low persistence firms will be predominant especially during years with earnings increases. They observe very little difference in abnormal returns across high and low persistence firms during years with earnings decreases, because they tend to be transitory rather than persistent. To make sure that the decrease in persistence is not driven by these transitory earnings decreases, we estimate the persistence parameters separately within the sample of firm-years with positive earnings changes and within the sample of firm-years with negative earnings changes (panels B and C respectively). Results confirm our conclusion from Panel A, namely that the persistence of earnings has declined in the post-regulation period and that this decline is primarily driven by the decline in the persistence of accruals.

\subsection{Robustness Evaluation}

To verify that our post-regulation results were not due to omitted correlated factors that were not specific to only U.S. capital markets, we use a control sample of European listed firms that were unaffected by the regulation in the U.S. 
Similar to Lee et al. (2014) we used European listed firms from 15 countries (Austria, Belgium, Denmark, Finland, France, Germany, Greece, Ireland, Italy, Netherlands, Norway, Spain, Sweden, Switzerland, and the UK). (Note 7) We re-performed our initial assessment of whether the sign of the change in annual earnings is associated with the sign of abnormal annual stock returns. For the U.S. firms, this analysis was presented in Table 2. The results from the analysis of the firm from the 15 European countries are presented in Table 6. Similar to the results previously described for the U.S. firms, the results indicate that the European firms with positive earnings changes have, on average, significantly higher cumulative abnormal returns than firms reported negative earnings changes. However, for the control group of European firms, there is no difference between the two time periods. Based on this, we conclude that regulation caused the changes in cumulative abnormal returns documented for U.S. firms.

Table 6. Annual Earnings Changes and Cumulative Abnormal Returns in International Sample

\begin{tabular}{|c|c|c|c|c|c|c|c|}
\hline & \multicolumn{3}{|c|}{$\begin{array}{l}\text { Panel A: Pre-Regulation Period } \\
\quad(1988.12-2000.09) \\
\end{array}$} & \multicolumn{3}{|c|}{$\begin{array}{l}\text { Panel B: Post-Regulation Period } \\
\quad(2003.05-2012.12)\end{array}$} & \multirow[t]{2}{*}{$\begin{array}{c}\text { Panel C: } \\
\text { Changes Post-Pre }\end{array}$} \\
\hline & \multicolumn{3}{|c|}{ Cumulative Abnormal } & \multicolumn{3}{|c|}{ Cumulative Abnormal } & \\
\hline Months & \multicolumn{3}{|c|}{ Returns for Firms with: } & \multicolumn{3}{|c|}{ Returns for Firms with: } & Changes in Diff \\
\hline Relative & Pos. & Neg. & & Pos. & Neg. & & \\
\hline to Earn. & Earnings & Earnings & Diff. & Earnings & Earnings & $\underline{\text { Diff. }}$ & $\Delta$ Diff. \\
\hline Ann. & Changes & Changes & & Changes & Changes & & \\
\hline-11 & 0.004 & -0.007 & 0.002 & 0.008 & -0.002 & $0.010 * * *$ & 0.008 \\
\hline-10 & 0.023 & -0.004 & 0.016 & 0.015 & -0.005 & $0.022 * * *$ & 0.006 \\
\hline-9 & 0.040 & -0.005 & $0.032 *$ & 0.026 & -0.011 & $0.038 * * *$ & 0.005 \\
\hline-8 & 0.064 & 0.002 & $0.047 * *$ & 0.037 & -0.016 & $0.053 * * *$ & 0.007 \\
\hline-7 & 0.095 & 0.006 & $0.071 * *$ & 0.051 & -0.018 & $0.072 * * *$ & 0.001 \\
\hline-6 & 0.121 & 0.016 & $0.093 * * *$ & 0.064 & -0.023 & $0.090 * * *$ & -0.003 \\
\hline-5 & 0.148 & 0.027 & $0.100 * * *$ & 0.075 & -0.027 & $0.103 * * *$ & 0.003 \\
\hline-4 & 0.177 & 0.040 & $0.110^{* *}$ & 0.088 & -0.031 & $0.122 * * *$ & 0.012 \\
\hline-3 & 0.206 & 0.047 & $0.124 * *$ & 0.097 & -0.033 & $0.132 * * *$ & 0.008 \\
\hline-2 & 0.224 & 0.041 & $0.135 * *$ & 0.108 & -0.034 & $0.145^{* * *}$ & 0.011 \\
\hline-1 & 0.241 & 0.046 & $0.144 * *$ & 0.119 & -0.038 & $0.160 * * *$ & 0.016 \\
\hline 0 & 0.273 & 0.038 & $0.180^{* *}$ & 0.143 & -0.044 & $0.190 * * *$ & 0.010 \\
\hline 1 & 0.284 & 0.042 & $0.186^{* *}$ & 0.152 & -0.043 & $0.198 * * *$ & 0.012 \\
\hline 2 & 0.299 & 0.042 & $0.197^{* *}$ & 0.161 & -0.045 & $0.209^{* * *}$ & 0.011 \\
\hline 3 & 0.316 & 0.046 & $0.202 * *$ & 0.166 & -0.050 & $0.218^{* * *}$ & 0.017 \\
\hline 4 & 0.326 & 0.049 & $0.206^{* *}$ & 0.172 & -0.052 & $0.228 * * *$ & 0.022 \\
\hline 5 & 0.339 & 0.059 & $0.206^{* *}$ & 0.182 & -0.052 & $0.238 * * *$ & 0.032 \\
\hline 6 & 0.350 & 0.064 & $0.214 * *$ & 0.189 & -0.053 & $0.246 * * *$ & 0.032 \\
\hline
\end{tabular}

We repeat the test presented in Table 2 using a sample of international firms obtained using Compustat Global (countries included in the analysis are Austria, Belgium, Denmark, Finland, France, Germany, Greece, Ireland, Italy, Netherlands, Norway, Spain, Sweden, Switzerland, UK). We include all firms from the aforementioned countries for which we can calculate the variables of interest. The overall sample covering the period 1995 through 2012 has a total of 34,425 firm-year observations. Panel A presents the results for the period pre-regulation, while Panel B repeats the test for the post-regulation period. Panel $\mathrm{C}$ examines if the differences between the cumulative abnormal returns for firms with positive and negative earnings changes have changed in the post-regulation period relative to the pre-regulation period. $*, * *, * * *$ denote statistical significance at the $10 \%, 5 \%$ and $1 \%$ level, respectively.

Another robustness check that we performed was a regression analysis that takes into consideration that the costs and benefits of complying with the regulatory changes could vary among firms. The results of this analysis are presented in Table 7. We include size and market-to-book as controls (These are well documented explanatory variables for 
returns. See the vast literature starting with Fama \& French, 1992). Included in Table 7 are the results for four models. Each of the models includes the variable Regulation_Dummy which is an indicator variable for whether the firm year was after 2002. This variable controls for the effect of regulation and is expected to have a positive coefficient. The first model includes $\Delta$ Earnings and the interaction term $\Delta$ Earnings $\mathrm{x}$ RegulationDummy. As anticipated the coefficient on $\Delta$ Earnings is positive and significant while the coefficient of $\Delta$ Earnings $\mathrm{x}$ RegulationDummy is negative and significant. This confirms our prior finding that the market response to earnings is significantly reduced during the post-regulation period. In Models 2 and 3 the two components of earnings, accruals and cash flow from operation are analyzed along with the interaction term. Again, the coefficient on the component of earnings is positive and significant but the coefficient on the interaction terms is negative and significant. Finally, in Model 4, both of the earnings components are included along with the interaction terms and the results are similar to the other models. This robustness check also confirms our prior findings that the market response to earnings is positive but significantly reduced in the post-regulation period.

Table 7. The Effect of Regulation on the Relation between Cumulative Returns and Changes in Earnings, Cash

\begin{tabular}{lcccc} 
Flows and Accruals & $(1)$ & $(2)$ & $(3)$ & $(4)$ \\
\hline Model & 0.115 & 0.112 & 0.117 & 0.117 \\
\hline Intercept & $(4.057)$ & $(3.962)$ & $(4.144)$ & $(4.153)$ \\
RegulationDummy & 0.011 & 0.011 & 0.012 & 0.012 \\
& $(1.982)$ & $(1.951)$ & $(2.112)$ & $(2.073)$ \\
Earnings Chg & 0.084 & & & \\
& $(7.363)$ & & & \\
Earnings Chg x RegulationDummy & -0.059 & & & \\
& $(-4.759)$ & & & \\
Accrual Chg & & 0.013 & & $(7.453)$ \\
& & $(2.787)$ & & -0.056 \\
Accrual Chg x RegulationDummy & & -0.010 & & $(-4.697)$ \\
Cash Flow Chg & & $(-2.111)$ & & 0.104 \\
& & & 0.028 & $(8.924)$ \\
Cash Flow Chg x RegulationDummy & & & -0.026 & -0.077 \\
Ln_MtB & & & $(-4.456)$ & $(-6.006)$ \\
Ln_ME & -0.035 & -0.035 & -0.035 & -0.035 \\
& $(-6.071)$ & $(-5.990)$ & $(-5.965)$ & $(-6.063)$ \\
& -0.004 & -0.004 & -0.004 & -0.004 \\
& $(-2.616)$ & $(-2.519)$ & $(-2.732)$ & $(-2.729)$ \\
\hline
\end{tabular}

We run a pooled regression at yearly level for our complete sample for the period 1988 to 2012, where the left hand side variable is annual returns; RegulationDummy takes value of 1 for years after 2003 and 0 otherwise; Earnings Chg, Accrual Chg and Cash Flows Chg are defined as described in Table 1. Ln_ME is the natural logarithm of size, defined as price $\mathrm{x}$ shares outstanding from Compustat (PRCC_C x CSHO). Ln_MtB is the natural logarithm of Market-to-Book, defined as market value of equity (ME) divided by book value of equity (BE), where ME is PRCC_C x CSHO and BE is stockholders' equity (SEQ) + Deferred Taxes (TXDB) + Investment Tax Credit (ITCB) - Preferred Stock (PSTKRV or PSTKL or PSTK). Numbers in parentheses are t-statistics calculated using two-way clustered standard errors in order to control for firm and year fixed effects.

Overall, our robustness checks support the conclusion that our results are indicative of widespread changes in the market response to earnings. 


\section{Summary and Conclusions}

Motivated by the extensive regulatory changes in the reporting environment made between the years 2000 and 2003, we investigate the overall effect of these regulatory changes on the relationship between earnings and returns association. Our results confirm a significant relation between earnings and returns and also that changes in annual earnings contain substantially more value-relevant information than changes in annual cash flows from operations. This highlights that the information contained in accounting accruals continues to be relevant for market participants. Perhaps more importantly, our results indicate that the relation between earnings and returns is significantly weaker after the regulatory changes. Furthermore, we provide evidence that the diminished market response to earnings can be the result of decreased earnings quality, by showing that earnings persistence coefficients have significantly decreased in the post-regulation period. This decrease is mainly driven by the decrease in the quality (persistence) of the accrual component of earnings. Overall, our results indicate that there was a significant change in how the market interprets earnings after the group of regulatory changes we address were implemented.

Periodically reassessing the core relation between earnings and returns is important especially given the extensive changes in the U.S. economic and regulatory environment between the years 2000 and 2003. In spite of the many positive consequences of these regulatory changes for the capital markets, our results raise a red flag by pointing out that after these changes there has been a general decrease in the quality of earnings (captured by decreased earnings persistence) which in turn has resulted in a weakened relation between earnings and returns. One limitation of our research is that our findings may not be applicable to other instances of regulatory change. It may be that the combination of regulatory changes addressed in this paper were unique in their effect on the market response to earnings.

\section{References}

Altamuro, J., \& Beatty, A. (2010). How does internal control regulation affect financial reporting? Journal of Accounting and Economics, 49(1-2), 58-74. http://dx.doi/org/10.1016/j.jacceco.2009.07.002

Ball, R., \& Brown, P. (1968). An Empirical Evaluation of Accounting Income Numbers. Journal of Accounting Research, (Autumn), 159-179. http://dx.doi.org/10.2307/2490232

Beaver, W. H. (1968). The Information Content of Annual Earnings Announcements. Journal of Accounting Research, 6(Supplement), 67-92. http://dx.doi/org/10.2307/2490070

Black, D. E., Black, E. L., Christensen, T. E., \& Heninger, W. G. H. (2012). Has the Regulation of Pro Forma Reporting in the US Changed Investors 'Perceptions of Pro Forma Earnings Disclosures ? Journal of Business Finance and Accounting 876-904. http://dx.doi/org/10.1111/j.1468-5957.2012.02297.x

Chang, H., Fernando, G. D., \& Liao, W. (2009). Sarbanes-Oxley Act, perceived earnings quality and cost of capital. Review of Accounting and Finance, 8(3), 216-231. http://dx.doi/org/10.1108/14757700910980831

Choi, J. H., Kalay, A., \& Sadka, G. (2015). Expected Earnings, Earnings News and Aggregate Stock Returns. Journal of Financial Markets, Forthcoming.

Cohen, D. A., Dey, A., \& Lys, T. Z. (2008). Management in the Pre- and Post-Sarbanes-Oxley Periods. The Accounting Review, 83(3), 757-787. http://dx.doi.org/10.2308/accr.2008.83.3.757

Collins, D. W., \& Kothari, S. P. (1989). An analysis of intertemporal and cross-sectional determinants of earnings response coefficients. Journal of Accounting and Economics, 11, 143-181. http://dx.doi.org/10.1016/0165-4101(89)90004-9

Dechow, P., Ge, W., \& Schrand, C. (2010). Understanding earnings quality: A review of the proxies, their determinants and their consequences. Journal of Accounting and Economics, 50(2-3), 344-401. http://dx.doi/org/10.1016/j.jacceco.2010.09.001

Easton, P. D., \& Zmijewski, M. E. (1989). Cross-sectional variation in the stock market response to accounting earnings announcements. Journal of Accounting and Economics, 11, 117-141. http://dx.doi.org/10.1016/0165-4101(89)90003-7

Eleswarapu, V. R., Thompson, R., \& Venkataraman, K. (2004). The impact of Regulation Fair Disclosure: Trading costs and information asymmetry. Journal of Financial and Quantitative Analysis, 39(2), 209-225. http://dx.doi.org/10.1017/S0022109000003045

Eng, L. L., Ha, J., \& Nabar, S. (2013). The impact of regulation FD on the information environment: evidence from 
the stock market response to stock split announcements. Review of Quantitative Finance and Accounting, 43(4), 829-853. http://dx.doi/org/10.1007/s11156-013-0394-4

Fama, E. F., \& French, K. R. (1992). The Cross-Section of Expected Stock Returns. The Journal of Finance, 47(2), 427-465. http://dx.doi.org/10.1111/j.1540-6261.1992.tb04398.x

Heflin, F., Subramanyam, K. R., \& Zhang, Y. (2003). Regulation FD and the Financial Information Environment: Early Evidence. The Accounting Review, 78(1), 1-37. http://dx.doi/org/10.2308/accr.2003.78.1.1

Herrmann, D., Kang, T., \& Kim, J. (2010). International Diversification and Management Earnings Guidance: The Effects of Reg FD. Journal of International Accounting Research, 9(1), 1-22. http://dx.doi/org/10.2308/jiar.2010.9.1.1

Hirshleifer, D., Hou, K., \& Teoh, S. H. (2009). Accruals, cash flows, and aggregate stock returns. Journal of Financial Economics, 91(3), 389-406. http://dx.doi/org/10.1016/j.jfineco.2007.11.009

Iliev, P. (2010). The Effect of SOX Section 404 Compliance on Audit Fees, Earnings Quality and Stock Prices. The Journal of Finance, 65(3), 1163-1196. http://dx.doi.org/10.1111/j.1540-6261.2010.01564.x

Jain, P. K., \& Rezaee, Z. (2006). The Sarbanes-Oxley Act of 2002 and Capital-Market Behavior: Early Evidence. Contemporary Accounting Research, 23(3), 629-654. http://dx.doi/org/10.1506/2GWA-MBPJ-L35D-C4K6

Kalelkar, R., \& Nwaeze, E. T. (2011). Sarbanes-Oxley Act and the quality of earnings and accruals: Market-based evidence. Journal of Accounting and Public Policy, 30(3), 275-294. http://dx.doi/org/10.1016/j.jaccpubpol.2011.02.004

Koch, A. S., Lefanowicz, C. E., \& Robinson, J. R. (2013). Regulation FD: A Review and Synthesis of the Academic Literature. Accounting Horizons, 27(3), 619-646. http://dx.doi/org/10.2308/acch-50500

Kormendi, R., \& Lipe, R. (1987). Earnings Innovations, Earnings Persistence, and Stock Returns. Journal of Business, 60(3), 323-345. http://dx.doi.org/10.1086/296400

Kothari, S. P., Lewellen, J., \& Warner, J. B. (2006). Stock returns, aggregate earnings surprises, and behavioral finance. Journal of Financial Economics, 79(3), 537-568. http://dx.doi/org/10.1016/j.jfineco.2004.06.016

Landsman, W. R., \& Maydew, E. L. (2002). Has the Information Content of Quarterly Earnings Announcements Declined in the Past Three Decades? Journal of Accounting Research, 40(3), 797-808. http://dx.doi/org/10.1111/1475-679X.00071

Lee, E., Strong, N., \& Zhu, Z. J. (2014). Did Regulation Fair Disclosure, SOX, and Other Analyst Regulations Reduce Security Mispricing? Journal of Accounting Research, 52(3), 733-774. http://dx.doi/org/10.1111/1475-679X.12051

Li, H., Pincus, M., Olhoft, I., \& Olhoft, S. (2008). Market Reaction to Events Surrounding the Sarbanes-Oxley Act of 2002 and Earnings Management. The Journal of Law and Economics, 51(1), 111-134. http://dx.doi.org/10.1086/588597

Liu, J., \& Thomas, J. (2000). Stock Returns and Accounting Earnings. Journal of Accounting Research, 38(1), 71-101. http://dx.doi.org/10.2307/2672923

Lobo, G. J., \& Zhou, J. (2006). Did Conservatism in Financial Reporting Increase after the Sarbanes-Oxley Act ? Accounting Horizons, 20(1), 57-73. http://dx.doi.org/10.2308/acch.2006.20.1.57

Lobo, G. J., \& Zhou, J. (2010). Changes in discretionary financial reporting behavior following the Sarbanes-Oxley Act. Journal of Accounting, Auditing and Finance, 25(1), 1-26. Retrieved from http://jaf.sagepub.com/content/25/1/1.short

Nichols, D. C., \& Wahlen, J. M. (2004). How Do Earnings Numbers Relate to Stock Returns? A Review of Classic Accounting Research with Updated Evidence. Accounting Horizons, 18(4), 263-286. http://dx.doi/org/10.2308/acch.2004.18.4.263

Richardson, S., Tuna, İ., \& Wysocki, P. (2010). Accounting anomalies and fundamental analysis: A review of recent research advances. Journal of Accounting and Economics, 50(2-3), 410-454. http://dx.doi/org/10.1016/j.jacceco.2010.09.008

SECURITIES AND EXCHANGE COMISSION (SEC). (2000). Selective disclosure and insider trading. Release 33-7881, Washington, DC. 
SECURITIES AND EXCHANGE COMISSION(SEC). (2003). Regulation Analyst Certification. Releases 33-8193, 34-47384. Washington, DC.

SECURITIES AND EXCHANGE COMMISSION (SEC). (2002). SEC, NY Attorney General, NASD, NASAA, NYSE and State Regulators Announce Historic Agreement to Reform Investment Practices. Release 2002-179. Washington, DC.

Sloan, R. (1996). Do Stock Prices Fully Reflect Information in Accruals and Cash Flows about Future Earnings? Accounting Review, 71(3), 289-315. Retrieved from http://www.jstor.org/stable/10.2307/248290

Stunda, R. (2012). Regulation fair disclosure (Reg FD) and its impact on earnings forecasts. International Journal of Business and Social Science, 3(17), 18-23. Retrieved from http://jwpress.com/IJABW/Issues/IJABW-Spring-2013.pdf\#page $=89$

Zhou, J. (2008). Financial reporting after the Sarbanes-Oxley Act: Conservative or less earnings management? Research in Accounting Regulation, 20(07), 187-192. http://dx.doi/org/10.1016/S1052-0457(07)00210-X

\section{Notes}

Note 1. In contrast to firm-level studies, some market-level analyses show that the relation between aggregate earnings changes and aggregate stock returns is negative (Kothari, Lewellen, \& Warner, 2006, Hirshleifer, Hou, \& Teoh, 2009). Choi et al. (2013) argue that this negative relation results from the expected component of aggregate earnings, rather than aggregate earnings news.

Note 2. Dechow et al., 2010 provide a thorough review on the literature focused on the information content of earnings in general, and ERC in particular.

Note 3. We use the daily returns with NYSE/AMEX/NASDAQ capitalization deciles to identify the corresponding size-decile return.

Note 4. Our results are qualitatively similar when we use earnings scaled by assets.

Note 5. Note that this does not allow the persistence parameters to change through time, since they are in-sample estimates. While time-varying persistence parameters are obviously desirable, using annual data limits the number of observations available for estimation.

Note 6. Untabulated results show that the difference in cumulative returns between firms with positive and negative CF changes (presented in Table 3 ) is in almost all cases statistically significantly larger than the equivalent difference in cumulative returns between firms with positive and negative accrual changes (presented in Table 4).

Note 7. Lee et al. (2014) used these 15 countries and also included Portugal for a total of 16 countries. We were unable to include Portugal due to data limitations on Compustat Global. 